Vol. 2, No. 2, 2021

Yuriy Royko, Yurii Yevchuk, Romana Bura

Lviv Polytechnic National University

12, Bandery Str., Lviv, 79000, Ukraine

(C) Yu. Royko, Yu. Yevchuk, R. Bura, 2021

https://doi.org/10.23939/tt2021.02.030

\title{
MINIMIZATION OF TRAFFIC DELAY IN TRAFFIC FLOWS WITH COORDINATED CONTROL
}

\begin{abstract}
Summary. The method and results of transport research, carried out by field research method, on the determination of the main indicators of traffic flows with significant unevenness of the movement on the arterial street in conditions of coordinated control is reviewed in the paper. Time parameters of traffic light control for which a reduction in traffic delay is achieved in direct and opposite traffic flow by the change of permissive signal depending on traffic intensity are determined using the simulation method. Change (increase) of the duration of the permissive signal provides uninterrupted movement of vehicles 'group during their passage of stop-line at traffic light objects. The proposed method can be used on sections of transport networks with coordinated control, where there is significant heterogeneity of traffic flow, and it prevents the dissipation of groups that consist of vehicles with different dynamic characteristics. Such a result is being performed in the case when in the system of automated control, which combines adjacent intersections on an arterial street, fixed-time program control of traffic light signalization is operating. In this condition, there is a possibility to adjust the duration of signals of traffic light groups by correcting the width (permissive signal duration) and angle of inclination (speed of movement) of the timeline in coordination graphs. The scientific novelty of this research is that the method of traffic delay minimization in conditions of coordinated control acquired further development. The essence of the method is in the controlled change of the range of permissive signal duration in conditions of simultaneous control of the speed of movement between adjacent intersections. Practical value is the application of different programs of traffic light control on sections of arterial streets in transport districts where a significant difference of values of traffic intensity by directions is in morning and evening peak periods.
\end{abstract}

Key words: transport research, traffic flow, coordinated traffic control, traffic light cycle duration, arterial street, simulation modelling, fixed-time program control, traffic flow composition..

\section{INTRODUCTION}

Implementing modern automated systems of traffic control on arterial streets that can provide the passage of intensive traffic flows is an essential component of improving the quality of transport service in large and especially large cities. By its functional purpose, arterial streets should provide rapid entry into or exit from the city of local and external transport with minimal delays and improve transport connection between separate large transport districts and functional zones. As a rule, public transport routes are also laid on such sections of the transport network and in particular, peripheral districts, the movement of freight transport is also provided. Such a road-transport situation complicates movement control as it is necessary to consider its significant volume and the heterogeneity of traffic flow.

In new cities, which began to develop actively in the last century, new transport networks were put in, which have a much more significant level of adaptation to the existing traffic intensity than cities where road network configuration developed historically. In "old" cities, up to two-thirds of the territory have 
dense built-up area and transport network that creates additional restrictions for the development of existing or implementation of new ways of traffic organization and traffic control. Despite that, transport problems are experienced by all cities, as motorization level and citizens" mobility grows rapidly, in "old" cities such critical (from the view of the effectiveness of transport service) factors are especially noticeable: insufficient free territory for transport interchanges arrangement; almost absent places for parking vehicles outside the road network; small (up to $100 \mathrm{~m}$ ) distances between intersections; narrow streets which do not allow to meet the demand for different ways of travel fully; saturated pedestrian flows with an approach to the city centre; the preferred radial type of transport network configuration, etc. Based on the above, special attention is paid by traffic organizers to the improvement of automated systems of traffic control and the implementation of transport system elements. Considering significant intensities of traffic and pedestrian flows and small intersections' area, most frequently, a single solution is the implementation of traffic light control. The most considerable effectiveness is reached in conditions of coordinated operation of adjacent traffic light objects and design of systems of coordinated control of movement. The precondition of it is carrying out field research to study the main indicators of traffic users, among which are traffic and pedestrian flows' intensity, their unevenness during the period of the most intensive movement (daytime), and traffic composition. Such information is the primary data for determining time parameters of traffic light control and simulation, which most frequently is carried out in specialized simulation program software. The unevenness of traffic flows by hours of the period of the most intensive movement is of great importance. It causes the review of control programs by separate directions to provide the balance of permissive signal duration due to the interrelation of the demand (traffic intensity), supply (maximal direction capacity), and delay minimization before the stop-line at signalized intersections. The solution to this problem for one isolated intersection is a relatively simple task. Still, in conditions of coordinated control, when there is a system of intersections, such a task is harder to implement.

\section{RESEARCH STATEMENT}

Existing theoretical and practical approaches to controlling traffic flow using traffic light control require constant improvement, the essence of which is in simultaneous consideration of a large amount of road-planning, transport and urban planning factors. In conditions of coordinated control, an important aspect is the design of such control algorithms, which would answer the high level of transport system reliability. By transport system reliability, we mean providing the uninterrupted passage of a group of vehicles through all stop-lines of the coordination system. Such a task can be completed by controlling the duration of permissive signals on traffic light objects and the movement speed simultaneously, as controlling traffic intensity, as derivative of travel demand, is quite complicated. Fixed-time algorithms that are tied and dependent on the "leading" (key) intersection of control are used in coordination systems. Considering that, we need to determine such a limit of acceptable values of the duration of the permissive signal in a coordinated direction depending on traffic intensity and composition, which would have the most negligible impact on the balancing of phase duration that complete a traffic light cycle at every intersection of the system. Herewith, simultaneous control of speed should implement such its value with which the most negligible dissipation of vehicle group during the passage of all stop-lines of coordinated direction will be reached. It means providing a minimal level of "diffusion" in traffic flow, considering its intensity and composition. Rational interrelation of these indicators will minimize the delay on arterial streets without violating the criteria requirements to coordinated control implementation.

\section{RELEVANCE OF THE STUDY}

The best efficiency in road users` flows control is reached by implementing elements of Intelligent Transport Systems. Their main task is a constant adaptation of regulatory regimes based on the indicators of road users. Mostly it is about traffic and passenger flows. Such adaptation can be carried out only using traffic light control that is synchronized with the informational support of the 
transport process. By informational support, the constant informing of road users about the change in the road-transport situation is meant here.

The diversity of methods and techniques that exist at this time focuses on one of the groups of road users - personal transport, public transport, or pedestrians. The combination of interests of these groups is quite rare, which is explained by the necessity of giving them particular priority during the passage of signalized (by traffic lights) sections of the transport network. As in conditions of coordinated traffic control, the usage of adaptive cycles is impossible, and then the priority is focused on only one of the groups, mainly personal transport, including trucks. Public transport is quite rarely considered as the necessity of compulsory technical stops for boarding and alighting of passengers destroys the timeline of coordinated control. Based on this, the design of such coordination systems, which considers traffic flow composition, its unevenness by hours, and movement speed, is a topical task.

\section{AIM AND TASK OF THE RESEARCH}

The aim of this research is to minimize the delay in traffic flow movement, which is reached by the change of time parameters of traffic light control with fixed-time control programs in conditions of coordination of traffic flow movement depending on the indicators of traffic flow and the distance between adjacent stop-lines.

For achieving the aim of the study, such tasks are formed:

- to analyze the theoretical dependencies that characterize time losses in traffic flows on arterial transport networks with different regimes of traffic light control;

- to determine the main factors which cause the delay in traffic flow movement in conditions of operation of coordinated control systems;

- to carry out the field research with the determination of traffic flow intensity and composition on arterial streets where its significant unevenness during the period of most intensive movement is observed;

- to determine the regularities of the change of time parameters of traffic light cycle depending on traffic flow indicators and roadway parameters at which the lowest values of traffic delay are achieved;

- to develop recommendations about the implementation of coordinated control systems on arterial transport networks where significant intensity and uneven traffic flow is observed.

Such methods are used during the carrying out of this research: field research for determination of traffic flow indicators, traffic light regulation parameters; system analysis for establishing the relationship between transport and road-planning factors; methods of mathematical statistics during the processing of results of field research; mathematical modelling for design and the description of regularities between traffic flow indicators and parameters and regimes of regulation.

\section{ANALYSIS OF RESENT RESEARCH AND PUBLICATIONS}

During the implementation of coordinated control for traffic flow movement, considerable attention is focused on studying vehicles ' groups, namely their formation and dissipation. As we know, the group is forming at the stop-line during the restrictive signal. After turning on the permissive signal, the departure of the group begins. As the traffic flow is heterogeneous, such a group begins to dissipate during the movement on the section. Operational factors of vehicles have an impact on this process. Based on this, it is essential to analyze how the group of vehicles dissipates in the movement process by street sections with different distances between stop-lines to further balanced road space distribution [1].

So, in paper [2], based on the analytical dependencies that describe the process of formation of vehicle groups during their movement by straight sections of the transport network, such value of section length is obtained $(l)$, for which vehicle group will not dissipate but provide the uniform motion on arterial. Such length of the section is determined by the dependence [2]: 


$$
l \geq \max \left\{125 \cdot v \cdot \ln \frac{G}{P_{1}(0)}, 125 \cdot v \cdot \ln \frac{T-G}{P_{2}(0)}\right\},
$$

where $v$-average flow speed; $G$ - moment in time when the movement from conflicting direction begins; $T$ - traffic light cycle duration; $P_{i}(0)$ - time length of vehicle group at the approach to i-section.

The result of the research is a determination of limit values of section length on which time interval between groups does not exceed the average interval between vehicles in the group. It means that traffic flow becomes stationary under specific parameters of the section of the transport network (170-1200 m) that provides its constant movement.

In paper [3], the method is given, and field research is carried out on arterial transport network provided that the distance between adjacent stop-lines does not exceed $300 \mathrm{~m}$ and the traffic intensity is 400-600 auto/h per one lane. The result of this research is that the "sustainability" of vehicle groups is provided with simultaneous phase shifts considering traffic flow peculiarities. Peculiarities of traffic flow here include the unevenness of the movement, speed, advancing and overtaking, and also impact of traffic composition and road conditions. As opposed to the study [2], in paper [3], the research is carried out on transport networks with significant density.

Researchers in paper [4] also studied phase shift in coordination systems, which they had analyzed using the graph analytical method. Its essence is to build a traffic schedule for vehicle groups in a coordinate system "time - distance". Authors built "timelines" for straight and opposite directions, which analyzed the transformation in three stages: the creation of vehicle group during the departure of the queue from stop-line at the first intersection; group dissipation during its movement by section; group forming on the approach to the next intersection in the case of restrictive signal or with the presence of vehicle queue that entered the arterial from minor directions of the first intersection and was forced to stop on the restrictive signal. In the study [4], it is stated that during the movement by arterial street section with different queue length values that obstructs the traffic in "timeline", there is a change of the instantaneous value of traffic flow intensity. There is a zone in which drivers have to reduce the speed up to the complete stop in this case. Such zones are "bottlenecks" where capacity reduces significantly. Based on the study [4], traffic flow intensity has a significant impact on the effectiveness of coordinated control by the criteria of traffic delay minimization not only in the main (coordinated) direction but also in the minor direction.

In most famous studies, during the evaluation of the effectiveness of coordination, primary attention is paid to planning features of the roadway, particularly its geometry. Along with this, consideration of the random nature of traffic flow is also essential. Simulation modelling can simultaneously consider geometry and vehicle behaviour. In such models, which are given in the study [5], the actual randomness of processes on the city's transport network is taken into account. Appropriate behaviour models reflect it. The application of the Webster model deserves special attention. It is based on the random arrival of vehicles to the intersection, which is considered for coordination systems in papers [6, 7]. Here, the duration of traffic light cycles is determined with consideration of the geometric principle of phase shift calculation for all traffic light objects that create a coordination system. All listed methods emphasize the usage of fixed-time control algorithms, which, unlike adaptive, provide an opportunity to change time distribution between different phases and their order due to the actual road-transport situation [8].

Taking into account the fact that an equal number of vehicles could arrive at every next signalized intersection is quite rare in practice, the most precise assumption is that the incoming traffic flow at the intersection will have a Poisson nature [9]. It is the consequence of the interaction of a large number of events. Authors [9] state that designing coordination plans based on the immediate task of assessing vehicle group length in a coordination system (green wave) requires the assessment of the probability of the emergence of an incomplete group in different conditions. It is because such an event means the reduction of the effectiveness of the use of traffic light cycle duration on all signalized intersections of coordinated section and existing methods of organization of coordinated operation of traffic light objects together with methods of queue length assessment at isolated intersections do not provide this process. 
Special attention during the coordination graphs design should be paid to the study of traffic speed and intensity. Some researchers emphasize the values of instantaneous velocity [10]. Here the regimes of movement are justified with the use of this indicator. In this research, GPS trackers are used. They are installed on vehicles, which move in traffic flow. By this method, the speed gradient on different sections of the transport network can be determined. Other researchers [11-15] pay special attention to the indicator of intensity and "diffusion" of the vehicle group.

Regardless of methodological approaches, analyzed methods are based on the increase of the effectiveness of automated systems of traffic control functioning on studied transport networks (configuration, specifics of location relative to city territory), the nature of changes in traffic flow indicators, road conditions, etc.

\section{PRESENTATION OF BASIC MATERIAL}

A section of Chervonoi Kalyny Avenue in Lviv city from the intersection with Dovzhenka Street (I) to the intersection with Sykhivska Street (V) was chosen as the experimental section. The length of the section is about $600 \mathrm{~m}$. There are five traffic light objects, which are given in Fig. 1.

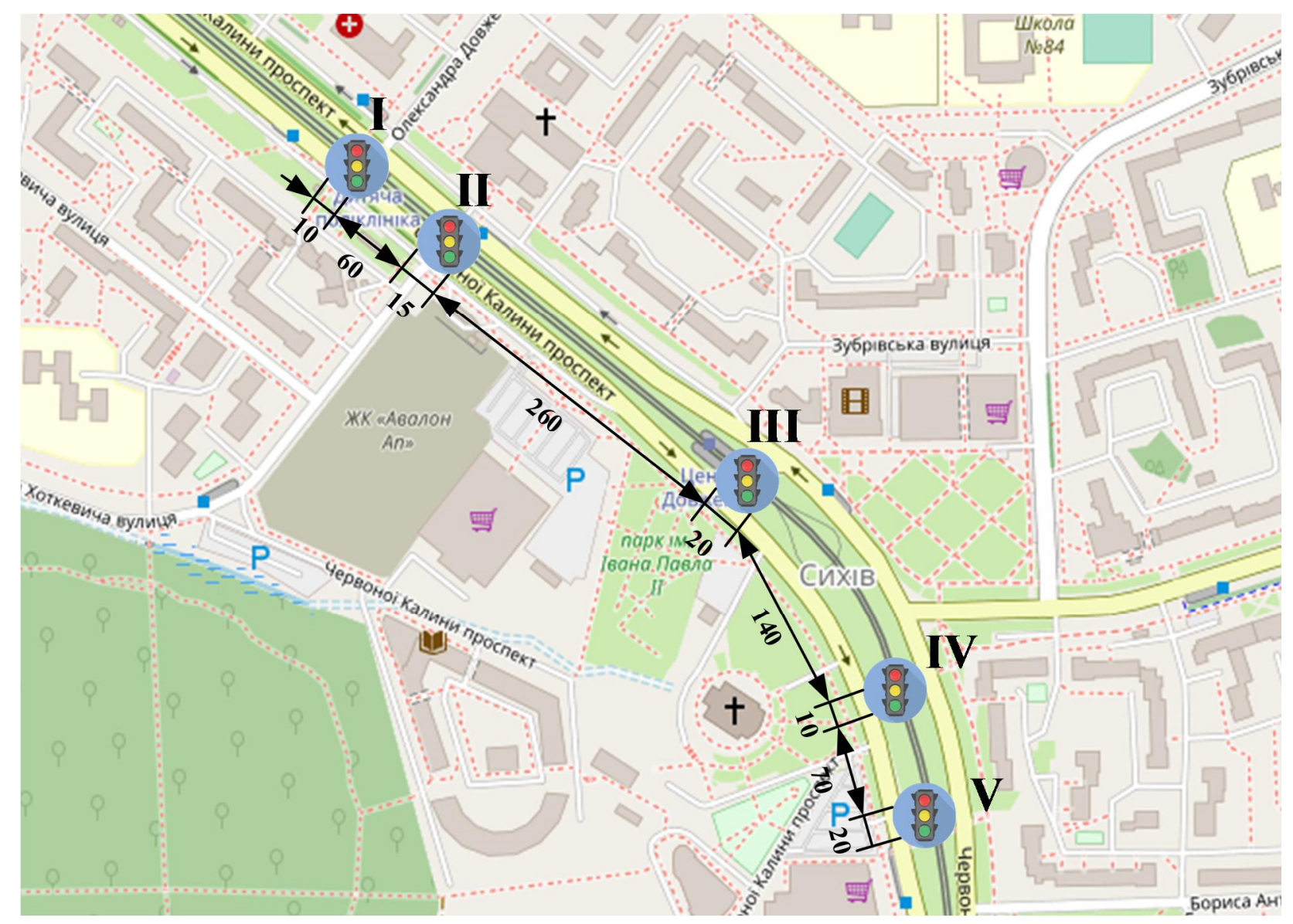

Fig. 1. Location of traffic light objects on the section of Chervonoi Kalyny Avenue:

I...V-numbers of traffic light objects (intersections and pedestrian crosswalks)

Using the field research method, we measured at every intersection (pedestrian crosswalk) traffic intensity with distribution by directions and determined traffic flow composition. Four measurements of 15 min each were carried out in peak periods. Results of research of these indicators for intersection (traffic light object) II is illustrated by cartogram, which is given for morning (Fig. 2) and evening (Fig. 3) peak periods. As traffic light object I is signalized pedestrian crosswalk, the intensity for it we accepted similar to the intensity in the main direction of intersection II. 

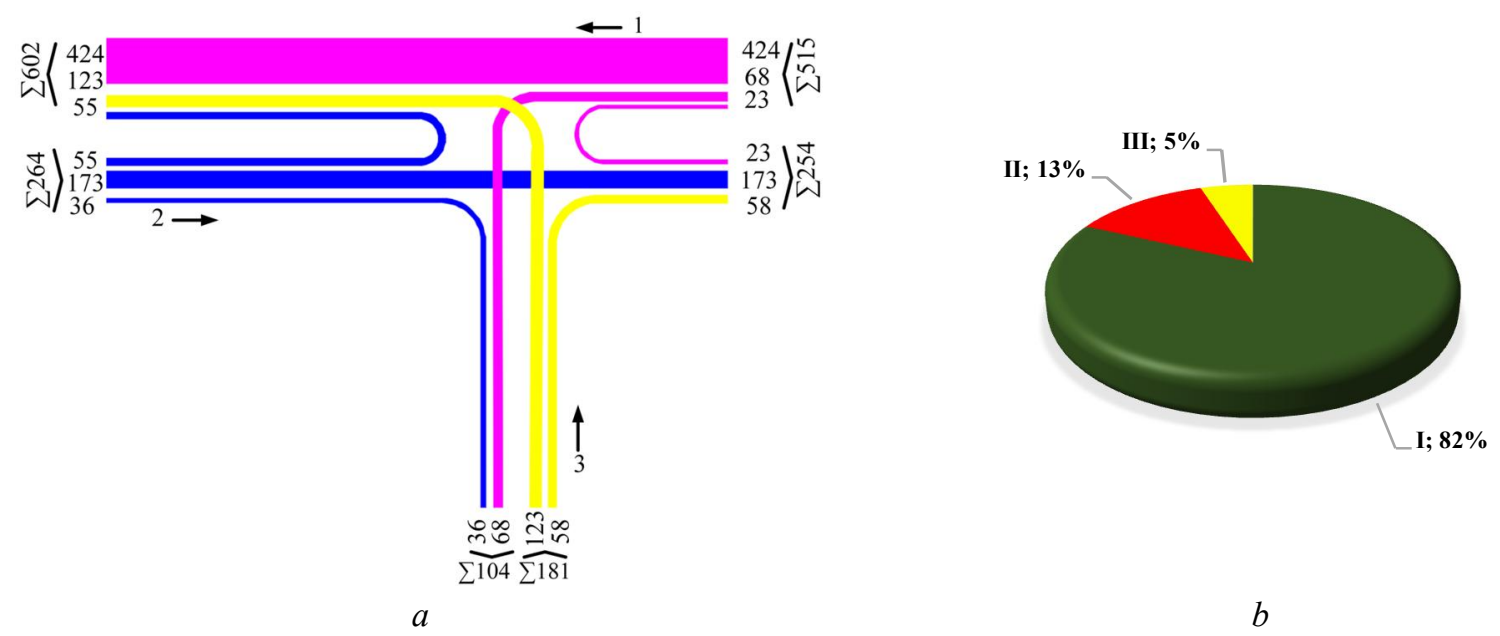

Fig. 2. Cartogram of intensity (a) and composition (b) of traffic flow in morning peak period at intersection II: I-cars; II - trucks; III - public transport; 1 - Chervonoi Kalyny Avenue "to the center";

2 - Chervonoi Kalyny Avenue "from the center"; 3 - secondary approach (Khotkevycha Street)
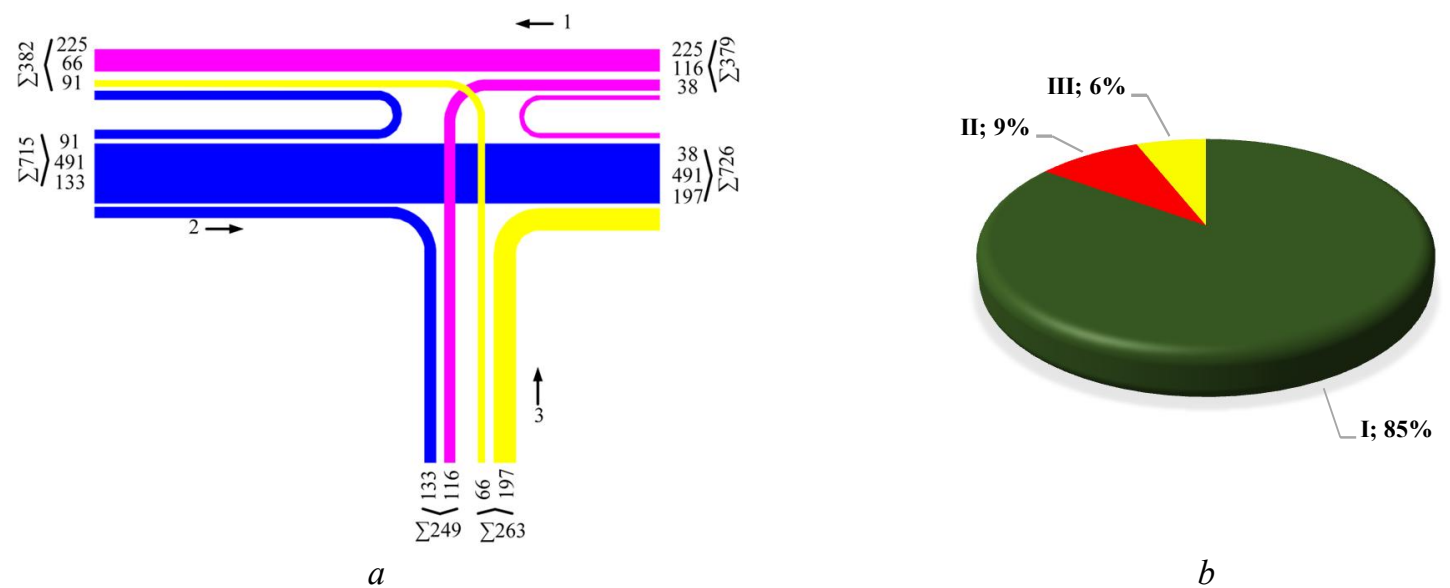

Fig. 3. Cartogram of intensity (a) and composition (b) of traffic flow in evening peak period at intersection II: I-cars; II-trucks; III - public transport; 1 - Chervonoi Kalyny Avenue "to the center";

2 - Chervonoi Kalyny Avenue "from the center"; 3 - secondary approach (Khotkevycha Street)

Results of measurements for other intersections (traffic light objects) are given in Fig. 4-9.

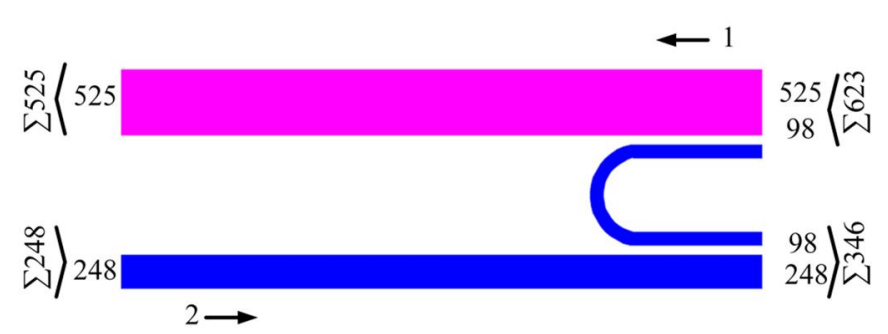

$a$

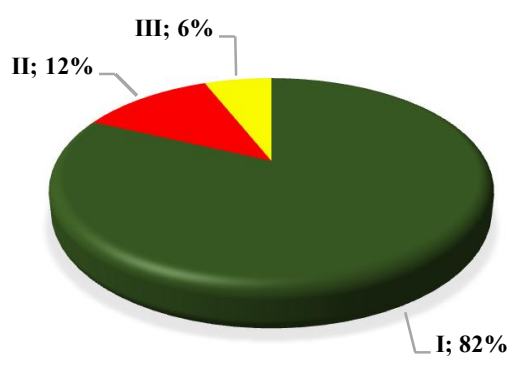

$b$

Fig. 4. Cartogram of intensity (a) and composition (b) of traffic flow in morning peak period at intersection III: I-cars; II-trucks; III - public transport; 1 - Chervonoi Kalyny Avenue "to the center";

2 - Chervonoi Kalyny Avenue "from the center" 


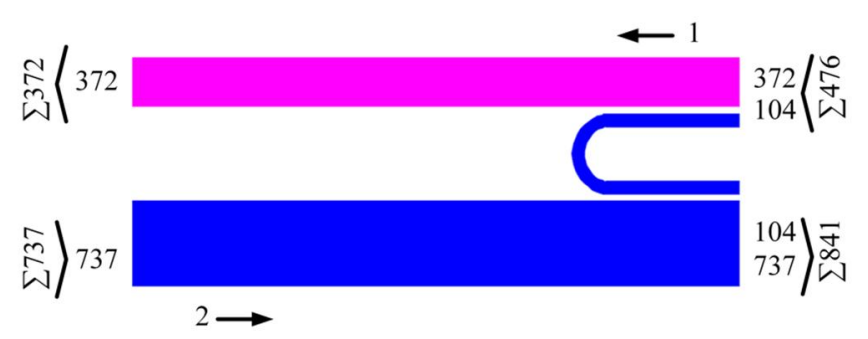

$a$

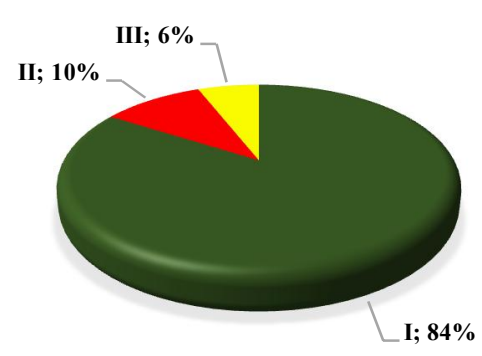

$b$

Fig. 5. Cartogram of intensity (a) and composition (b) of traffic flow in evening peak period at intersection III: I-cars; II-trucks; III - public transport; 1 - Chervonoi Kalyny Avenue "to the center"; 2 - Chervonoi Kalyny Avenue "from the center"
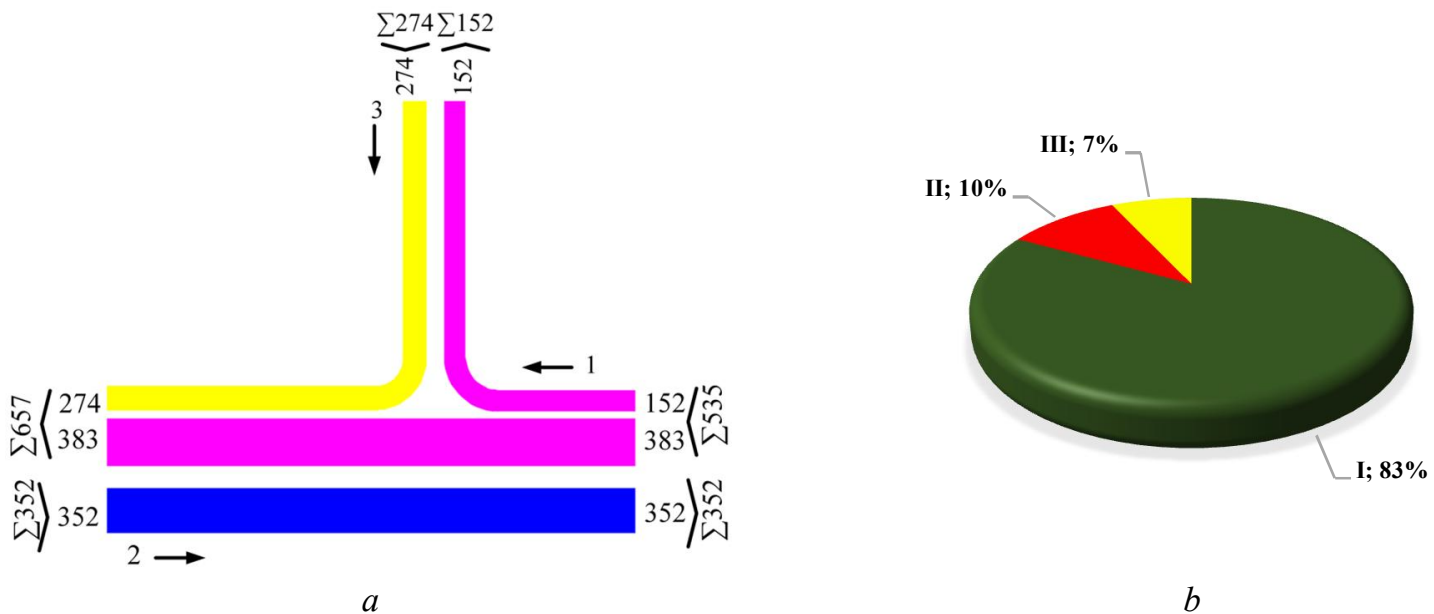

Fig. 6. Cartogram of intensity (a) and composition (b) of traffic flow in morning peak period at intersection IV: I-cars; II - trucks; III - public transport; 1 - Chervonoi Kalyny Avenue "to the center";

2 - Chervonoi Kalyny Avenue "from the center"; 3 - secondary approach (Sykhivska Street)

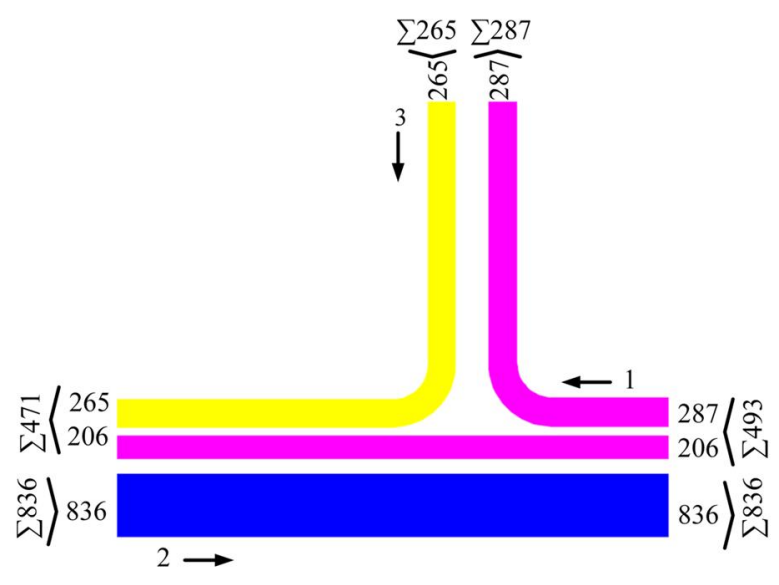

$a$

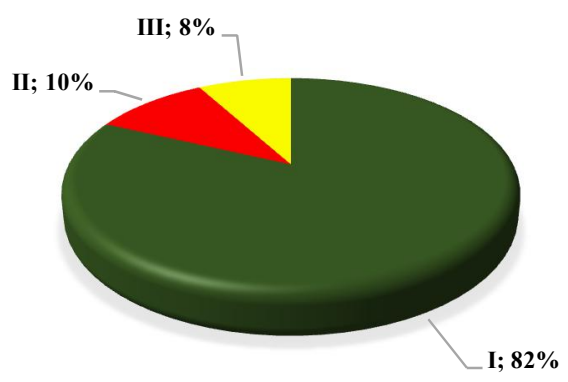

$b$

Fig. 7. Cartogram of intensity (a) and composition (b) of traffic flow in evening peak period at intersection IV: I-cars; II-trucks; III - public transport; 1 -Chervonoi Kalyny Avenue "to the center"; 2 - Chervonoi Kalyny Avenue "from the center"; 3 - secondary approach (Sykhivska Street)

Results of analysis of traffic intensity on a studied section of arterial street - Chervonoi Kalyny Avenue indicate its significant unevenness in morning and evening peak periods (Fig. 2-9). Here, we 
admit that the avenue has two lanes in every direction, separated by a median. In the morning peak period, intensity is: in direction to centre from about 400 auto/h to about 650 auto/h; in the direction from the centre - from about 200 auto/h to about 350 auto/h. In the evening peak period, we have the following range of intensity values: in direction to the centre from about 200 auto/h to about $500 \mathrm{auto} / \mathrm{h}$; in the direction from the centre - from about 700 auto/h to about 850 auto/h. Such asymmetric loading is inherent in transport districts, which have prevailing residential areas.

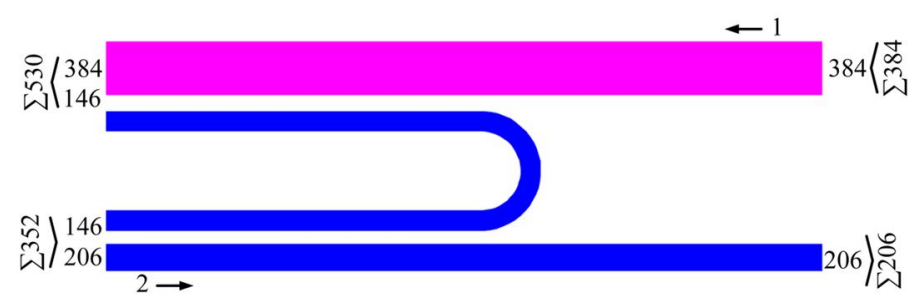

$a$

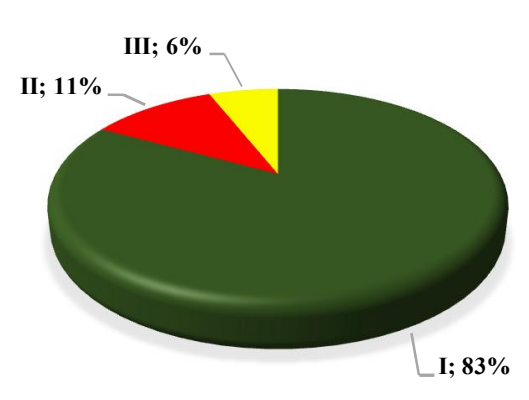

$b$

Fig. 8. Cartogram of intensity (a) and composition (b) of traffic flow in morning peak period at intersection $V$ : I-cars; II-trucks; III-public transport; 1 - Chervonoi Kalyny Avenue "to the center";

2 - Chervonoi Kalyny Avenue "from the center"
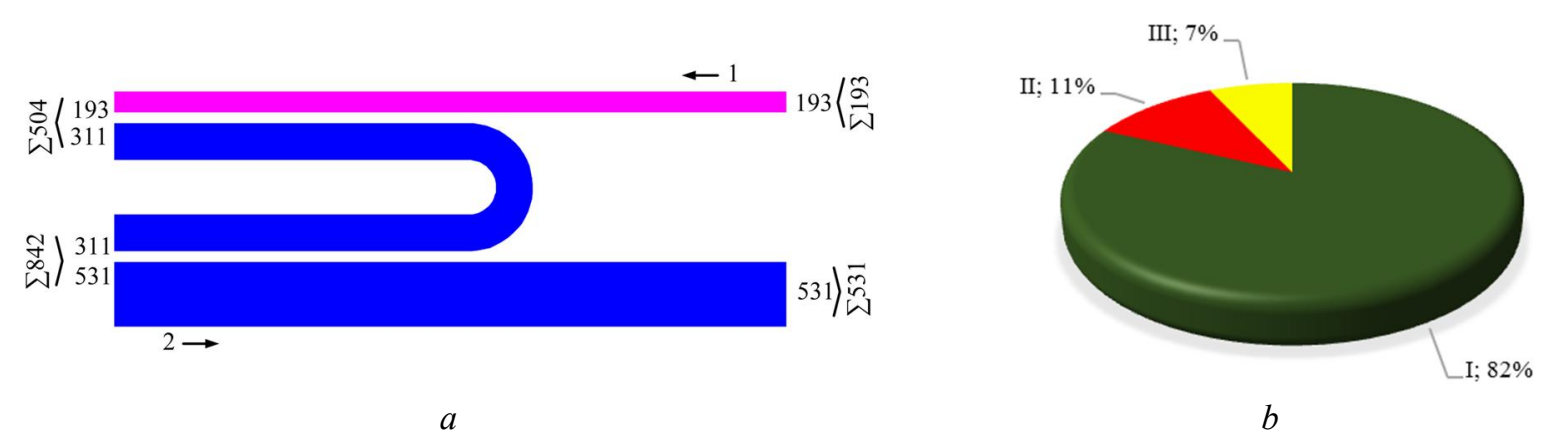

Fig. 9. Cartogram of intensity (a) and composition (b) of traffic flow in evening peak period at intersection $V$ : I-cars; II-trucks; III-public transport; 1 - Chervonoi Kalyny Avenue "to the center"; 2 - Chervonoi Kalyny Avenue "from the center"

Given results of field research is the primary information for entering into simulation program software PTV VISSIM, in which the model of an investigated section of the avenue is created. The main task is to obtain variable values of traffic delay for all traffic flow in conditions of coordination at stoplines I-IV, taking into account determined traffic intensity (Fig. 2-9), traffic flow composition (83\% of cars; $6 \%$ of buses, and $11 \%$ of trucks), calculated traffic light cycle for the leading (most loaded) intersection (pedestrian crosswalk), which is $70 \mathrm{sec}$. Such a duration of the traffic light cycle is set for all intersections of the coordination system. Another variable in this study is the speed of traffic flow movement, which is alternately included in the model with the following values: $40,45,50,55$, and $60 \mathrm{~km} / \mathrm{h}$.

Simulation results are given as Tables 1 and 2 .

Table 1

Traffic flow delay under different values of speed in morning peak period

\begin{tabular}{|c|c|c|c|c|c|}
\hline $\begin{array}{c}\text { Average delay of traffic flow at every stop- } \\
\text { line of studied section, sec }\end{array}$ & 40 & 45 & 50 & 55 & 60 \\
\cline { 2 - 6 } & 192 & 199 & 204 & 206 & 219 \\
\hline Movement in direction to the center & 29 & 31 & 30 & 30 & 33 \\
\hline Movement in direction from the center & & \multicolumn{5}{|c|}{ Speed $\mathrm{km} / \mathrm{h}$} & 30 \\
\hline
\end{tabular}


Traffic flow delay under different values of speed in evening peak period

\begin{tabular}{|c|c|c|c|c|c|}
\hline Average delay of traffic flow at every stop-line & \multicolumn{5}{|c|}{ Speed, $\mathrm{km} / \mathrm{h}$} \\
\cline { 2 - 6 } of studied section, sec & 40 & 45 & 50 & 55 & 60 \\
\hline Movement in direction to the center & 33 & 34 & 35 & 35 & 37 \\
\hline Movement in direction from the center & 154 & 156 & 156 & 162 & 164 \\
\hline
\end{tabular}

Graphical interpretation of research results, given in Tables 1 and 2, is given in Fig. 10-11.

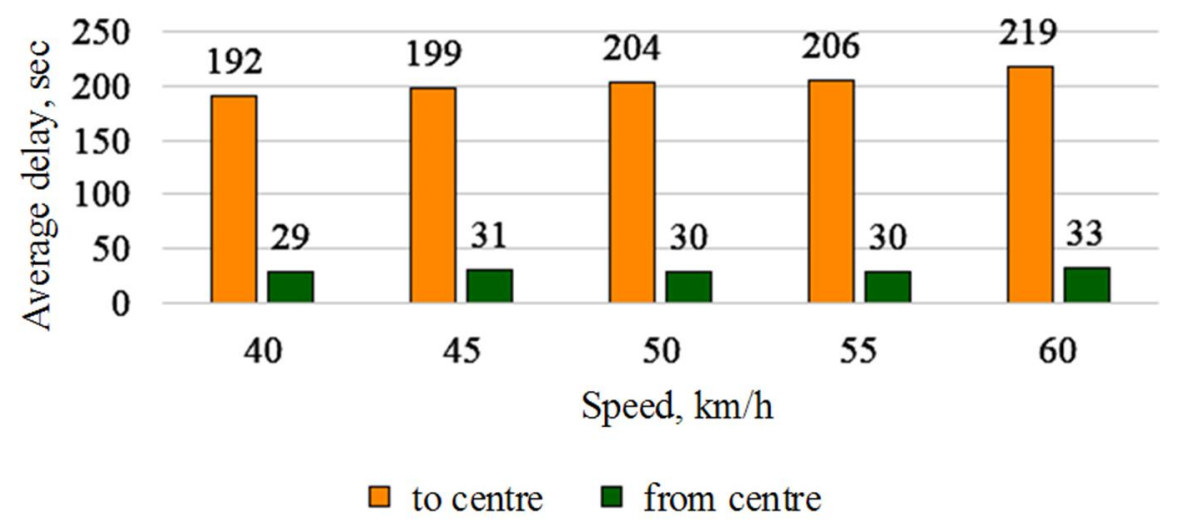

Fig. 10. Change of average delay in traffic flow depending on the speed of movement in morning peak period

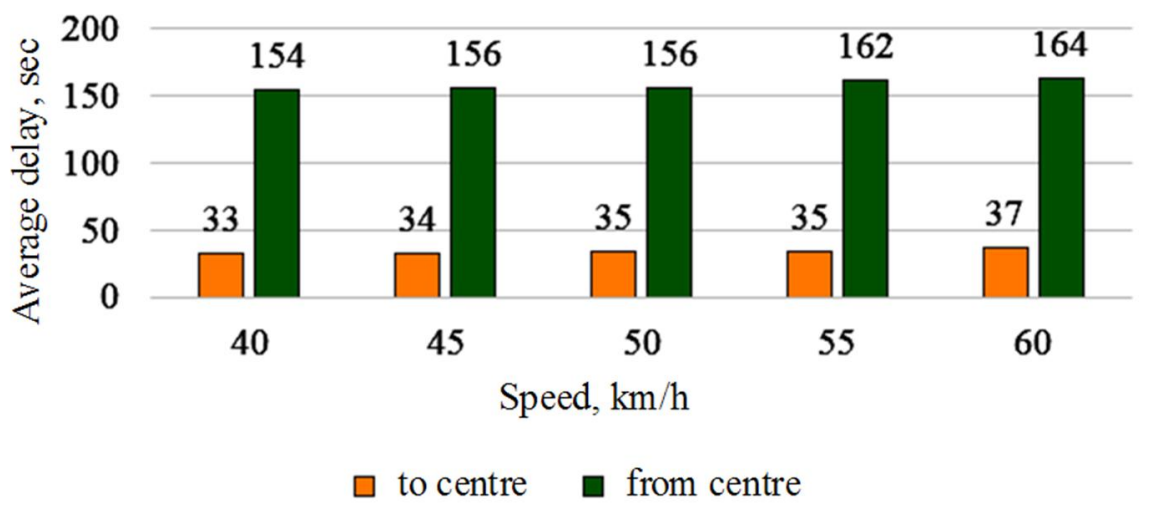

Fig. 11. Change of average delay in traffic flow depending on the speed of movement in evening peak period

Having analyzed the results of research (simulation), given in Fig. 10 and 11, we can conclude that in direction "to the centre" (morning peak period) with the increase of speed by $20 \mathrm{~km} / \mathrm{h}$, the average value of delay increases by $10 \%$, and in the opposite direction (evening peak period) with the same increase of speed, the delay increases by $6 \%$. Different shares of straight flows can explain the difference in dependencies for two opposite directions, as with a significant share of turn flows, the delay will increase.

In coordination systems, the necessary task is to provide the permanent motion of arterial transit traffic flows. As mentioned before, to achieve such a result in practice is a quite complicated task as during the movement in urban conditions, we observe a large sample size of a random variable - speed of movement, which is related to traffic flow composition. Based on this, the process of passage of traffic flow with measured indicators with the set speed of 40,50 , and $60 \mathrm{~km} / \mathrm{h}$ was simulated in PTV VISSIM. The duration of the permissive signal in the two-lane direction was $30 \mathrm{sec}$. During the simulation, the distance between stop-lines was changed to determine its impact on group dissipation. This experiment 
aimed to determine the need to increase the main (permissive) signal on the next stop-line (distance to which is variable) to allow passing the last vehicle from the queue which departed at the first intersection. Simulation results are given in Fig. 12.

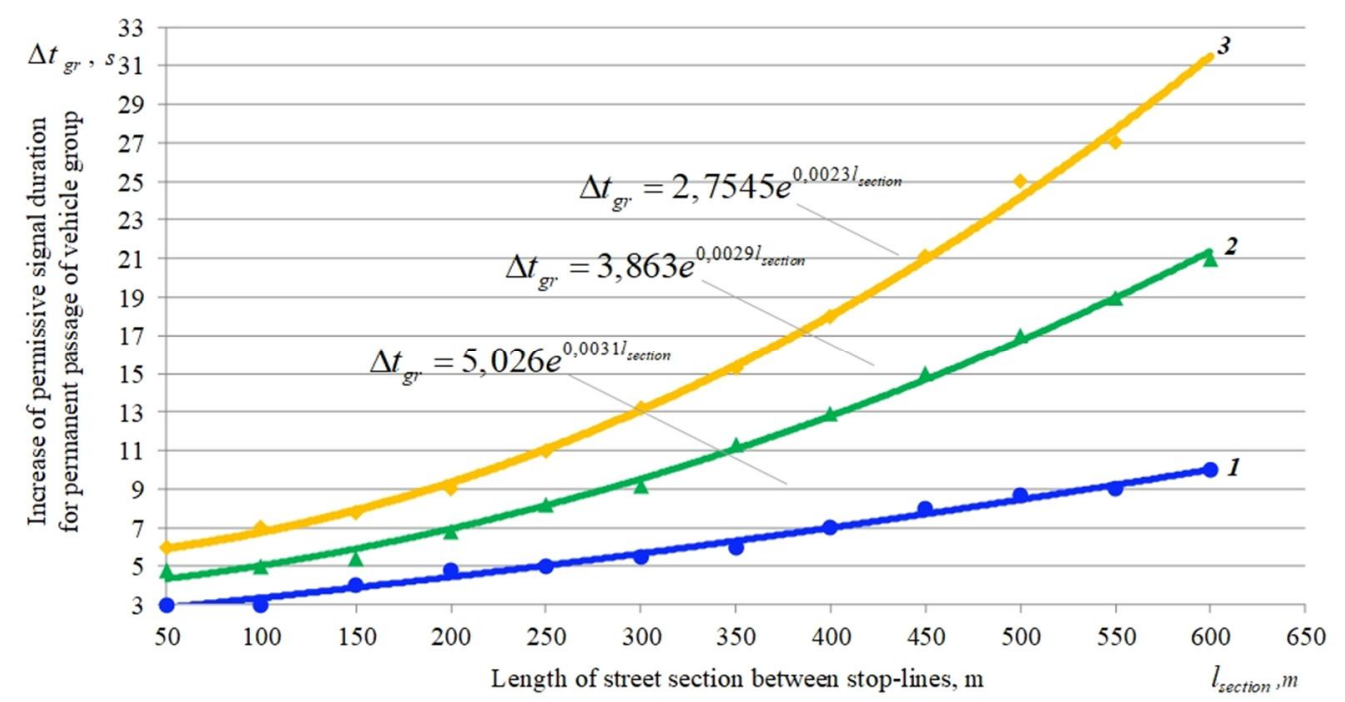

Fig. 12. Results of simulation of permissive signal duration increase (relative to the estimated), based on the criterion of delay minimization, depending on the length of street section between stop-lines with different speed of movement: $1-40 \mathrm{~km} / \mathrm{h} ; 2-50 \mathrm{~km} / \mathrm{h} ; 3-60 \mathrm{~km} / \mathrm{h}$

As a result of the simulation, we determined that the most stable (by criteria of speed) is traffic flow, which is guided by speed regime restriction in $40 \mathrm{~km} / \mathrm{h}$. In this case, with the increase of the distance between stop-lines from $50 \mathrm{~m}$ to $600 \mathrm{~m}$, the need for an increase of permissive signal duration at the next stop-line (at intersections or pedestrian crosswalks) increases from $3 \mathrm{sec}$ to $10 \mathrm{sec}$. At the same time, with the exact change of the distance between stop-lines with restriction of speed regime to $50 \mathrm{~km} / \mathrm{h}$, the increase of permissive signal can be about $20 \mathrm{sec}$, and with $60 \mathrm{~km} / \mathrm{h}-30 \mathrm{sec}$.

Based on the results of this research, the expediency of arrangement of intermediate stop-lines in coordination system can be justified, and the high level of traffic flow stability at the speed of $40 \mathrm{~km} / \mathrm{h}$ is confirmed. Indeed, such a statement is true for urban arterial streets with significant unevenness of traffic flow and with the presence of two lanes in one direction.

\section{CONCLUSIONS AND FUTURE RESEARCH PERSPECTIVES}

As a result of this scientific research, we can make such conclusions:

a) the main factors, which impact the effectiveness (by the criterion of traffic delay minimization) of coordinated control are traffic flow intensity and composition, speed of movement, the distance between stop-lines, duration of permissive signal in coordinated direction. The secondary factors are road pavement condition and the share of permissive signal in traffic light cycle in coordinated direction;

b) by results of simulation modelling, it is established that on a section of two-lane arterial street with coordinated movement, the value of delay in the flow changes from 154 to $219 \mathrm{sec}$ with the maximal intensity of traffic flow of 850 auto/h with a composition of $83 \%$ of cars, $6 \%$ of buses, and $11 \%$ of trucks during the change of designed speed (angle of inclination of the timeline) from 40 to $60 \mathrm{~km} / \mathrm{h}$ with the step of $5 \mathrm{~km} / \mathrm{h}$. Along with this, its least values appear with the speed of $40 \mathrm{~km} / \mathrm{h}$;

c) with the change of distance between stop-lines from 50 to $600 \mathrm{~m}$ and given values of traffic flow indicators (intensity and composition), the need in the extending the duration of permissive signal (with the established value of $30 \mathrm{sec}$ ) on the next (by direction of movement) stop-line for the provision of permanent motion is: for the speed of $40 \mathrm{~km} / \mathrm{h}$ - from 3 to $10 \mathrm{sec}$; for the speed of $50 \mathrm{~km} / \mathrm{h}$ - about $20 \mathrm{sec}$, and the speed $60 \mathrm{~km} / \mathrm{h}-30 \mathrm{sec}$. 
Further research on the solution of the formulated problem consists of the following:

- determination of traffic delay not only for vehicles but for transport system users (drivers and passengers);

- development of recommendations about the duration of permissive signal on coordinated arterial directions depending on the number of lanes and the share of public transport;

- consideration of unevenness of traffic flow by hours of the day during the calculation of speed of movement in coordination systems for straight and opposite directions.

An essential condition for achieving these aims is considering current tendencies and practical approaches in such fields and directions as urban planning, road construction and infrastructure, informatization and development of Artificial Intelligence systems, etc.

\section{References}

1. Currie, G., Sarvi, M., \& Young, W. (2007). Balanced Road Space Allocation: A Comprehensive Approach. ITE Journal on the Web, 75-83 (in English).

2. Abramova, L. (2019). Osoblyvosti modelyuvannya hrupovoho rukhu transportnykh zasobiv u mistakh [Features of modeling of group movement of vehicles in cities], International scientific and practical conference "Scientific achievements of modern society". Liverpool, United Kingdom, 8-16 (in Ukrainian).

3. Krystopchuk, M., Khitrov, I., Tson, O., \& Pochuzhevskyy, O. (2021). Doslidzhennya koordynovanoho upravlinnya transportnymy potokamy $\mathrm{v}$ tsentral'niy chastyni mista [Study of coordinated traffic management in the central part of the city]. Suchasni tekhnolohiyi $v$ mashynobuduvanni ta transporti [Advances in mechanical engineering and transport], Volume 1(16). 82-90 doi: 10.36910/automash.v1i16.511 (in Ukrainian).

4. Kulyk, M., \& Shyrin, V. (2019). Zabezpechennya staloyi shvydkosti transportnykh potokiv v rezhymi koordynovanoho upravlinni na mis'kykh mahistralyakh [Ensuring a constant speed of traffic flows in the mode of coordinated management on urban highways], Materialy IV mizhnarodnoyi naukovo-praktychnoyi konferentsiyi "Bezpeka na transporti - osnova efektyvnoyi infrastruktury: problemy ta perspektyvy" [Proceedings of the IV International scientific and practical conference on "Safety in transport - basis efficient infrastructure: problems and prospects"]. pp 238-241 (in Ukrainian).

5. Chen, C., Che, X., Huang, W., \& Li, K. (2019). A two-way progression model for arterial signal coordination considering side-street turning traffic. Transportmetrica B, 1627-1650 doi: 10.1080/21680566. 2019.1672590 (in English).

6. Canadian Capacity Guide for Signalized Intersections. (2008). Ottawa: Institute of Transportation Engineers (in English).

7. Signal Timing Manual. (2015). Second Edition. NCHRP Report 812. National Cooperative Highway Research Program. In Cooperation with U.S. Department of Transportation Federal Highway Administration (in English).

8. Gartner, N., Pooran, F., \& Andrews, C. (2002). Implementation and Field Testing of the OPAC Adaptive Control Strategy in RT-TRACS, Proc. Of $81^{\text {st }}$ Annual Meeting of the TRB. Oakland, CA, USA: IEEE, 148-156 doi :10.1109/ITSC.2001.948655 (in English).

9. Gorbachov, P., Makarichev, O., \& Shevchenko, V. (2021). Imovirnist' vynyknennya nepovnoyi pachky avtomobiliv pry koordynovanomu keruvanni na mis'kiy mahistrali [The probability of an incomplete pack of cars with coordinated driving on the city highway]. Visnyk Kharkivskoho natsionalnoho avtomobilno-dorozhnoho universytetu [Bulletin of Kharkiv National Automobile and Highway University], 92, 214-225 doi: 10.30977/BUL.2219-5548.2021.92.1.214 (in Ukrainian).

10. Ryabushenko, O., Nagluk, I., Shevtsov, D. (2019). Doslidzhennya rezhymu rukhu avtomobilya v umovakh mista za danymy GPS treku [The research of the driving mode of the vehicle in the urban conditions according to GPS track]. Visnyk Kharkivskoho natsionalnoho tekhnichnoho universytetu silskoho hospodarstva [Bulletin of Kharkiv Petro Vasylenko National Technical University of Agriculture], 198, 448-456. (in Ukrainian)

11. Ji, Y., Tang, Y., Wang, W., \& Du, Y. (2018). Tram-Oriented Traffic Signal Timing Resynchronization. Journal of Advanced Transportation. Volume 2018. doi: 10.1155/2018/8796250 (in English).

12. Shi, J., Sun, Y., Schonfeld, P., \& Qi, J. (2017). Joint optimization of tram timetables and signal timing adjustments at intersections. Transportation Research Part C: Emerging Technologies. Volume 83. 104-119. doi: 10.1016/j.trc.2017.07.014 (in English). 
13. Zhou, L., Wang, Yi., \& Liu, Ya. (2017). Active signal priority control method for bus rapid transit based on Vehicle Infrastructure Integration. International Journal of Transportation Science and Technology. Volume 6(2). 99-109. doi: 10.1016/j.ijtst.2017.06.001 (in English).

14. Vrubel, Yu.A (2007). Issledovania $\mathrm{v}$ dorozhnem dvizhenii: uchebno-metodicheskoe posobie $\mathrm{k}$ laboratornym rabotam [Research in traffic: study guide for laboratory work]. Minsk: BNTU (in Russian).

15. Scheffler, R., \& Strehler, M. (2017). Optimizing traffic signal settings for public transport priority. Proc. of the 17th Workshop on Algorithmic Approaches for Transportation Modelling, Optimization, and Systems (pp. 9:19:15) - Vienna, Austria. doi: 10.4230/OASIcs.ATMOS.2017 (in English).

Received 27.08.2021; Accepted in revised form 05.10.2021.

\title{
МІНІМІЗАЦІЯ ЗАТРИМКИ РУХУ У ТРАНСПОРТНИХ ПОТОКАХ ЗА КООРДИНОВАНОГО УПРАВЛІННЯ
}

\begin{abstract}
Анотація. У роботі розглянуто методику та результати транспортних досліджень, проведених методом натурних вимірювань, з визначення основних показників транспортних потоків зі значною нерівномірністю руху на магістральній вулиці в умовах координованого управління. Використовуючи метод імітаційного моделювання, визначено часові параметри світлофорного регулювання, за яких досягається зменшення затримки руху у прямому за зустрічному транспортному потоиі шляхом зміни тривалості дозвільного сигналу залежно від величини інтенсивності руху. Зміна (збільшення) тривалості дозвільного сигналу забезпечує беззупинний рух групи транспортних засобів під час їх проїзу через стоп-лінії на світлофорних об'єктах. Запропонований метод актуальний до застосування на ділянках транспортної мережі з координованим управлінням, де є значна неоднорідність транспортного потоку, i запобігає розпаду груп, які складаються із транспортних засобів з різними динамічними характеристиками.

Такий результат досягається у випадку, коли в системі автоматизованого управління, яка об'єднує суміжні перехрестя на магістральній вулиці, діє жорстке програмне управління світлофорною сигналізаиією. За такої умови є можливість узгодити тривалість сигналів світлофорних груп, коректуючи ширину (тривалість дозвільного сигналу) та кут нахилу (щвидкість руху) стрічки часу у графіках координації. Наукова новизна цього дослідження полягає в тому, що набув подальшого розвитку метод мінімізаиї̈ затримки транспорту в умовах координованого управління, суть якого полягає у керованій зміні діапазону тривалості дозвільного сигналу за одночасного управління швидкістю руху між суміжними перехрестями. Практична иінність - застосування різних програм управління світлофорною сигналізацією на ділянках магістральних вулиць у транспортних районах, де у ранішній та вечірній пікові періоди є значна відмінність значень інтенсивності руху за напрямками.

Ключові слова: транспортні дослідження, транспортний потік, координоване управління рухом, тривалість світлофорного циклу, магістральна вулиия, імітаційне моделювання, жорстке програмне управління, інтенсивність руху, склад транспортного потоку
\end{abstract}

